\title{
THE LIFE HISTORY AND DEVELOPMENT OF HYPOGLOSSUM RHIZOPHORUM (DELESSERIACEAE, RHODOPHYTA) IN CULTURE, A NEW DEEP-WATER SPECIES FROM THE CARIBBEAN ${ }^{1}$
}

\author{
David L. Ballantine ${ }^{2}$ \\ Department of Marine Sciences, University of Puerto Rico, Mayaguez, Puerto Rico 00708 \\ and \\ Michael J. Wynne \\ Department of Biology and Herbarium, University of Michigan, Ann Arbor, Michigan 48109
}

\begin{abstract}
Hypoglossum rhizophorum sp. nov. is described from deep coral reef habitats on the southern insular shelf of Puerto Rico and the western insular shelf of Basse Terre, Guadeloupe, occurring from 21 to $85 \mathrm{~m}$ in depth. The new species is also known from a single shallow-water collection in Hawaii. Plants grow from a prostrate nonfoliose rhizome producing simple, delicate erect blades at regular intervals. Reproductive plants were not collected in the field; isolated plants, however, readily reproduced in culture demonstrating a typical "Polysiphonia-type" life history. Spermatangial sori form coalesced oblique bands which are interrupted by secondary cell rows. Tetrasporangia are produced from both lateral and transverse pericentral cells, adjacent second-and third-order cells as well as cortical cells.
\end{abstract}

Key index words: Caribbean; culture; Delesseriaceae; Hypoglossum; Hypoglossum rhizophorum sp. nov.; life history; Rhodophyta

Hypoglossum is a large genus of the Delesseriaceae (Rhodophyta) with some 20 to 25 species known from warm waters worldwide (Wynne and Kraft 1985, Wynne and Ballantine 1986). The genus was characterized by Womersley and Shepley (1982) as comprised of plants with monostromatic blades (except at the midrib), in which branching originates at the midrib. Plants have initials of all third-order cell rows reaching the margin of blades; an absence of intercalary divisions; carposporangia formed in chains; and tetrasporangia which are formed from cortical cells, pericentral cells and/or cells of the second- and third-order cell rows. Five species are known from the North Atlantic of which four are known from the tropical western Atlantic (Wynne and Ballantine 1986): Hypoglossum hypoglossoides (Stackhouse) Collins \& Hervey, H. tenuifolium (Harvey) J. Agardh, $H$. involvens (Harvey) J. Agardh, and H. anomalum Wynne \& Ballantine. Recent deep-water collections off the southwest coast of Puerto Rico and in Guadeloupe resulted in the recognition of a

\footnotetext{
1 Accepted: 28 September 1987.

${ }^{2}$ Address for reprint requests.
}

new species of the genus. Its life history and morphological development in culture are reported.

\section{MATERIALS AND METHODS}

Plants collected by SCUBA and with the manipulative collecting arm of the Johnson Sea-Link II submersible were preserved in $5 \%$ formalin-seawater immediately after collection. Wholemount slides were prepared of thalli stained in acidified $1 \%$ aniline-blue in $60 \%$ Karo syrup. Line drawings were made with the aid of an Olympus research microscope with camera lucida. Voucher specimens of the Puerto Rico and Guadeloupe collections have been deposited at the Herbarium of the Department of Marine Sciences, University of Puerto Rico (MSM) and at the United States National Herbarium, Department of Botany, Smithsonian Institution (US). Herbarium abbreviations are according to Holmgren et al. (1981).

Culture methods. Sterile plants were collected from the type locality (4.xii.1985) at a depth of $30 \mathrm{~m}$; all cultures were initiated from this material. Carolina Alga Gro medium prepared at $1 / 8$ strength in filtered sterile seawater was utilized. Clean blades, relatively free of epiphytic growth, were placed into culture dishes with a volume of $150 \mathrm{~mL}$ media. Germanium dioxide at a concentration of $5 \mathrm{mg} \cdot \mathrm{L}^{-1}$ was added initially to control diatom contamination. Tetraspores and carpospores on release were pipetted into fresh culture dishes with glass coverslips placed on the bottom. All cultures were maintained in a Percival model I-30B incubator at $26^{\circ} \mathrm{C}$ and at a photon flux density of $15 \mu \mathrm{E}$. $\mathrm{m}^{-2} \cdot \mathrm{s}^{-1}$ with a $12: 12 \mathrm{~h} \mathrm{LD}$ regime.

\section{RESULTS AND DISCUSSION}

\section{Diagnosis: Hypoglossum rhizophorum sp. nov.}

Laminae erectae delicatae, e costa rhizomatum prostratorum singulatim aut inaeque binatim productae; laminae $1.3 \mathrm{ad} 2.3$ (3.2) $\mathrm{mm}$ long. atque 400 ad 900 (1100) $\mu \mathrm{m}$ lat.; omnes cellulae serierum cellularum secundi ordinis series cellularum tertii ordinis procreant; rhizomata vulgo teretia et saepe ramosa, ad $80 \mu \mathrm{m}$ diam., aut raro anguste expansa, usque ad $200 \mu \mathrm{m}$ et 15 cellulas lat.; rhizomata ad origonem ramorum erectorum constricta teretiave; rami erecti intervallis 12 ad 16 segmenta procreati, non vicissum ramosi, nisi situ injuriae; plantae fasciculis rhizoideum uniseriatorum, quae e cellulis pericentralibus atque e cellulis ordinum cellularum lateralium innascantur, affixae; rhizoidea adversum ramos erectos plerumque sita; rhizoidea solum loco tactus cum substrato ramosa; omnes plantae collectae steriles.

Delicate erect blades produced singly or in unequal pairs from midrib of prostrate rhizome; blades 1.3 to $2.3(3.2) \mathrm{mm}$ in length and 400 to 900 (1100) 
$\mu \mathrm{m}$ in width; all cells of second-order cell rows produce third-order cell rows; rhizomes generally terete and frequently branched, to $80 \mu \mathrm{m}$ in diameter, or rarely are narrowly expanded, to $200 \mu \mathrm{m}$ and 15 cells in width; rhizomes constricted or terete at origin of erect branches; erect branches produced at intervals of 12 to 16 segments, not rebranched except at site of injury; plants attached by clusters of uniseriate rhizoids originating from pericentral cells and cells of the lateral cell rows; rhizoids generally positioned opposite from the erect branches; rhizoids branched only at point of contact with substratum; all collected plants sterile.

Holotype: D. L. Ballantine 1750b, 16.i.1985, $61 \mathrm{~m}$ depth, edge of insular shelf, offshore from La Parguera, Puerto Rico. Deposited at the Herbarium of the University of Michigan ( $\mathrm{MICH}$ ). Isotypes deposited in MSM and US.

Additional collections: Puerto Rico. Edge of insular shelf offshore from La Parguera: Ballantine 84, 10.iii.1978 (21 m on Verongia); Ballantine 1718b, 16.i.1985 (58 m); Ballantine 1832, 11.i.1985 (40 m). Edge of insular shelf offshore from Salinas: Ballantine 891a, 5.i.1982 (31 m); Ballantine 908, 11.i.1982 $(31 \mathrm{~m})$. Edge of insular shelf offshore from Guanica: Ballantine $2157 \mathrm{~b}, 11 \mathrm{x} .1985(85 \mathrm{~m}$, collected from Johnson Sea-Link submersible). Guadeloupe. Edge of insular shelf, Malendure, Basse Terre: Ballantine 2478 and Wynne 8349, 24.ii.1987 (31 m). Hawaii. Makiwa, east of Olowalu, Maui Island: $I$. A. Abbott 14519, 28.viii.1978 (1-3 m; Coll. by D. P. Abbott).

\section{Life History and Development in Culture}

Within 17 days of culture initiation, tetrasporangia were produced. Tetrasporangial production is initiated near the apex along the midrib and then proceeds outward from the midrib (Fig. 2). The sorus is covered by a cortical layer of cells and is elongate extending continuously along the midrib to an indefinite length. Sorus widths ranged from 200 to $400 \mu \mathrm{m}$. Tetrasporangia were produced on both blade surfaces and were observed to be irregularly distributed throughout the sorus with a mixture of different stages of development. Tetrasporangia were produced by pericentral cells, cells of the second- and third-order cell rows as well as from cortical cells. Mature tetrasporangia were tetrahedrally divided reaching $60 \mu \mathrm{m}$ in diameter.

Tetraspores on release germinated within $24 \mathrm{~h}$. The first division was unequal, the smaller division product becoming the rhizoidal initial (Fig. 7). Both cells continued to divide such that by the end of the second day the axial row was six cells in length and branching was initiated from the rhizoidal hapteron (Fig. 8). After four days, axial cells at a position of two to three segments behind the apical cell divided to form lateral pericentral cells, and the first lateral initials from the newly cutoff pericentral cells were apparent (Fig. 9). By the sixth day of development, erect thalli were recognizable as blades with secondorder cell rows initiating third-order cell rows (Fig. 10 ). Within 10 days (Fig. 11) cell rows of the blade were further developed and rhizoids were greatly increased in length. Following the differentiation of the primary erect blade, typically two lateral prostrate filaments were formed from one of the basal axial cells. These filaments constituted the rhizome, which creeps over the substratum and gives rise to new erect blades at regular intervals. Figure 12 shows a 23-day-old plant in which the primary erect blade is fully developed and has produced two prostrate rhizomes, one of which has initiated a new erect blade. The prostrate rhizomes were normally five cells in width although it was not uncommon in cultured plants to find erect branches which had developed rhizoids from the apical region and become prostrate. In such cases new erect branches were initiated from the apex, and the newly prostrate blade continued prostrate growth.

Maturation of gametophytic plants required six weeks following release of tetraspores. Plants were dioecious with male and female plants observed in approximately equal numbers. Male plants were initially recognizable by small isolated spermatangial patches on mature blades (Fig. 3). Spermatangia were initiated almost entirely by cells of the third-order cell rows. With maturation, spermatangial sori coalesced to form opposite obliquely placed bands which were interrupted by the second-order cell rows (Fig. 4). The sori extended approximately $2 / 3$ the width of the blade from just outside the pericentral cells. Occasionally spermatangia were seen over portions of the second-order cell rows. This pattern of spermatangial banding across the cells of tertiary cell rows is also seen in $H$. harveyanum (J. Agardh) Womersley \& Shepley (Womersley and Shepley 1982).

Procarps were abundantly produced along the blade midrib with trichogynes projecting to $90 \mu \mathrm{m}$ in length, apparently extending in a direction perpendicular to the plane of the blade. Procarps positioned on the central axial filament are illustrated in Figure 5 with the four-celled carpogonial branches evident. Fertilization was not observed; however, it was assumed to have taken place. Mature cystocarps are hemispherical in shape with a single prominent ostiole. Pericarps were twice observed to form over as many as three developing procarps. Mature cystocarps (Fig. 6) measured up to $385 \mu \mathrm{m}$ in diameter.

The development of carpospores was similar to that of tetraspores described above with the exception that an alternate sporeling development was also seen. In this pattern, early development was entirely prostrate through at least six days of growth with the initial rhizoid becoming considerably more elongate (Fig. 13) than in erectly developing sporelings. In some instances (Fig. 13) rhizoidal filaments were produced from the apices after minimal blade 


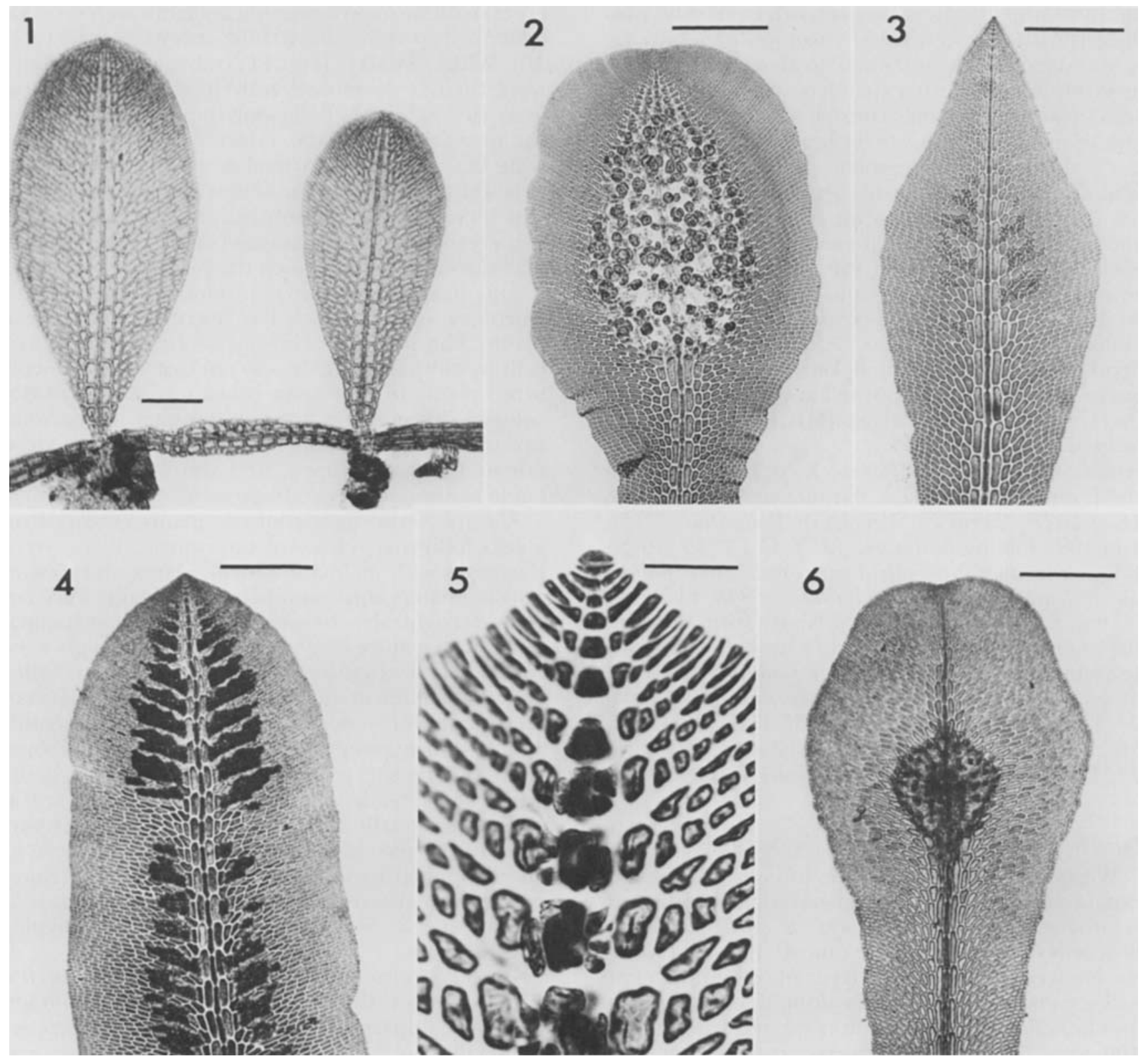

Figs. 1-6. Hypoglossum rhizophorum sp. nov. Fig. 1. Habit of wild plant. Scale bar $=100 \mu \mathrm{m}$. Figs. 2-6. Cultured plants. Fig. 2. Tetrasporophytic blade. Scale bar $=250 \mu \mathrm{m}$. Fig. 3. Male gametophytic plant with initial production of spermatangial clusters. Scale bar $=250 \mu \mathrm{m}$. Fig. 4. Male gametophytic plant with mature spermatangial sori coalesced into discrete oblique bands. Scale bar $=250$ $\mu \mathrm{m}$. Fig. 5. Procarps on consecutive axial row cells. Scale bar $=25 \mu \mathrm{m}$. FIG. 6 . Erect blade with solitary cystocarp. Scale bar $=250 \mu \mathrm{m}$.

development in addition to the normally placed rhizoids. The prostrate blade-like thallus continued development in breadth and length before finally initiating an erect branch (Fig. 14). This type of prostrate filament was observed once from wild material. Tetrasporophytic plants matured and produced sporangia approximately four weeks after germination.

Cultured plants in most instances retained a form very similar to that seen in wild plants (Fig. 1) although there was a tendency for some blades to become spirally twisted shortly after isolation. Many cultured plants also showed a slightly undulate mar- gin not seen in wild plants. The most striking departure from normal morphology was seen in a few second generation tetrasporophyte plants. These displayed a pattern of marginal branching not typical of the genus Hypoglossum but rather similar to that in Branchioglossum.

Distribution and Comparison with other Hypoglossum Species

Hypoglossum rhizophorum is a broadly distributed species, now known from the Caribbean and Hawaii. It is apparently restricted to deep-water habitats in its west Atlantic distribution. It is of interest 

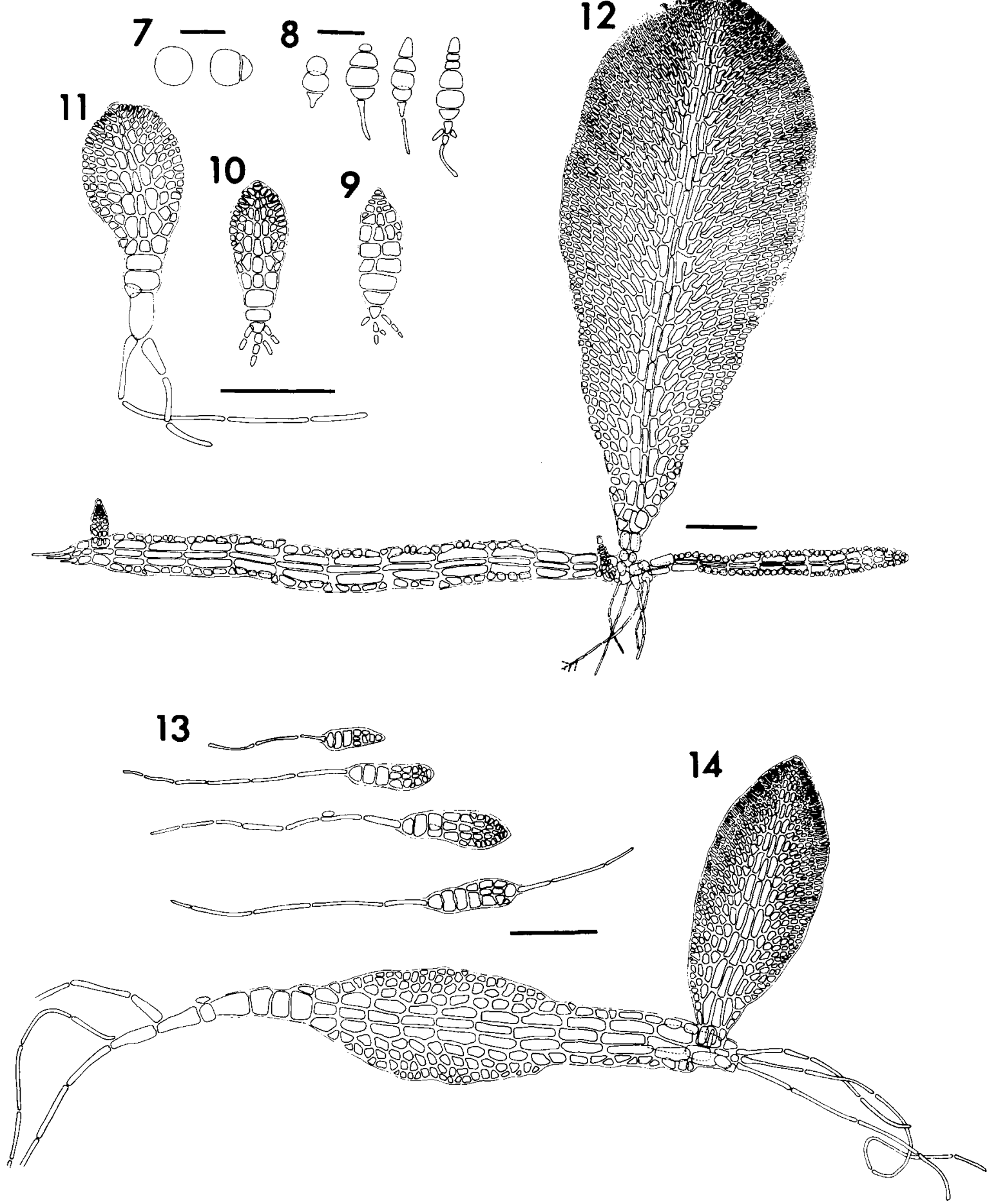

Figs. 7-14. Cultured Hypoglossum rhizophorum sp. nov. Fig. 7. Tetraspore and first division. Scale bar $=50 \mu \mathrm{m}$. Fig. 8. Development through 2 days. Scale bar $=50 \mu \mathrm{m}$. Fig. 9. Development through 4 days. Fic. 10. Development through 6 days. Fig. 11 . Development through 10 days. Scale bar for Figures $9-11=100 \mu \mathrm{m}$. Fig. 12. Three week old plant. Scale bar $=100 \mu \mathrm{m}$. Fig. 13. Prostrate sporeling development. Fig. 14. Production of erect blade from prostrate system. Scale bars for Figures $13-14=100 \mu \mathrm{m}$.

that the single collection from the Pacific was from a shallow-water site.

Among the Caribbean species of the genus, $H y$ poglossum rhizophorum resembles $H$. hypoglossoides, $H$. involvens, and $H$. anomalum in possessing blades in which all cells of the second-order rows produce third-order cell rows although it shares a prostrate habit only with $H$. anomalum. The new species differs from $H$. anomalum, however, in a number of respects. In $H$. anomalum the normal vegetative blades 
are prostrate, whereas erect blades are produced in the new species from a prostrate rhizome. Hypoglossum anomalum is otherwise easily distinguished from the new species in its unique branching habit, where paired branches separate from the parent blade at a point between their origin at the midrib and the blade margin.

In a previous culture study of the genus, Notoya (1986) obtained a "Polysiphonia-type" life history in H. nipponicum Yamada. In that species antheridial sori were developed as discrete patches from more or less isolated vegetative cells and did not form the broad confluent spermatangial sori observed in $H$. rhizophorum. Tetrasporangia were not produced from transverse pericentral cells in $H$. nipponicum, a characteristic also differing from the new species.

Hypoglossum rhizophorum somewhat resembles $H$. caloglossoides Wynne \& Kraft, another member of the genus with a prostrate habit. As was the case with $H$. anomalum, the prostrate axes in $H$. caloglossoides are less rhizome-like than those in $H$. rhizophorum. The new species is also smaller than $H$. caloglossoides. Reproductively $H$. caloglossoides differs from cultured $H$. rhizophorum in having smaller tetrasporangia and in the nature of the spermatangial sorus. In $H$. rhizophorum, spermatangia are in oblique bands while they are coalesced across second-order cell rows in $H$. caloglossoides.

Yoshida and Mikami (1986) recently published an account of two other Japanese species of Hypoglossum, both species consisting of blades less than $1 \mathrm{~cm}$ tall, The blades of H. minimum Yamada are usually simple and attached by a small basal disc, and thus are unlike the rhizomatous system of $H$. rhizophorum. In $H$. geminatum Okamura, on the other hand, the primary blade does have a prostrate habit, with secondary blades arising in pairs from the dorsal surface of the primary blade. As in $H$. caloglossoides, the primary axes in $H$. geminatum are less rhizome-like than in the new species, and blades are always produced in opposite pairs rather than the single or unequal paired arrangement in $H$. rhizophorum. In addition, tetrasporangia in $H$. geminatum are produced only from cells of the second-order rows, re- sulting in a single layer of tetrasporangia (Yoshida and Mikami 1986). This pattern differs from that in $H$. rhizophorum in which tetrasporangia are produced from both inner cells and cortical cells of the blade.

Another Japanese species demonstrating a prostrate habit is H. barbatum Okamura (Okamura 1900). Okamura depicted a decumbent alga in which blades of various orders produced marginal rhizoids in abundance. The primary blade of $H$. barbatum was not narrowly rhizomatous as in the new species.

We wish to acknowledge the financial support to D.L.B. from the Office of Research Coordination, University of Puerto Rico, Recinto Mayaguez and to M.J.W. from National Science Foundation research grant BSR-8516669. Some of the specimens were collected during a cooperative research study of deep-water fauna and habitats by the National Marine Fisheries Service, University of Puerto Rico Sea Grant Program, CODREMAR of the Commonwealth of Puerto Rico, the Department of Conservation and Cultural Affairs of the Government of the Virgin Islands and the Caribbean Fishery Management Council of Puerto Rico and the U.S. Virgin Islands. We thank the captain and crew of the RV Seward Johnson and submersible Johnson Sea-Link Il for their assistance. Dr. Aline Renoux, Universite Antilles-Guyane, Pointea-Pitre greatly facilitated collection in Guadeloupe. Ms. Gladys Collazo assisted in preparation of the line drawings and Dr. Hannah Croasdale translated the Latin diagnosis.

Holmgren, P. K., Keuken, W. \& Schofield, E. K. 1981. Index Herbariorum. Part I. The Herbaria of the World. Ed. 7. Bohn, Scheltema \& Holkema, Utrecht (Regnum Vegetabile Vol. 106), 452 pp.

Notoya, M. 1986. Hypoglossum nipponicum Yamada (Delesseriaceae, Rhodophyta) in culture. Jap. J. Phycol. 34:28-30.

Okamura, K. 1900. Illustrations of the Marine Algae of Japan. Vol. 1(2), pls. 6-10, Tokyo.

Womersley, H. B. S. \& Shepley, E. A. 1982. Southern Australian species of Hypoglossum (Delesseriaceae, Rhodophyta). Austral. J. Bot. 30:321-46.

Wynne, M. J. \& Ballantine, D. L. 1986. The genus Hypogiossum Kützing (Delesseriaceae, Rhodophyta) in the tropical western Atlantic, including $H$. anomalum sp. nov. J. Phycol. 22:18593.

Wynne, M. J. \& Kraft, G. T. 1985. Hypoglossum caloglossoides sp. nov. (Delesseriaceae, Rhodophyta) from Lord Howe Island, South Pacific. Br. Phycol. J. 20:9-19.

Yoshida, T. \& Mikami, H. 1986. Observations on morphology of Hypoglossum minimum Yamada and $H$. geminatum Okamura (Delesseriaceae, Rhodophyta). Jap. J. Phycol. 34:177-84. 